\title{
Race, Gender, and Information Technology Use: The New Digital Divide
}

\author{
LINDA A. JACKSON, Ph.D., ${ }^{1}$ YONG ZHAO, Ph.D., ${ }^{2}$ ANTHONY KOLENIC III, M.A., ${ }^{3}$ \\ HIRAM E. FITZGERALD, Ph.D., ${ }^{1}$ RENA HAROLD, Ph.D., ${ }^{4}$ \\ and ALEXANDER VON EYE, Ph.D. ${ }^{1}$
}

\begin{abstract}
This research examined race and gender differences in the intensity and nature of IT use and whether IT use predicted academic performance. A sample of 515 children (172 African Americans and 343 Caucasian Americans), average age 12 years old, completed surveys as part of their participation in the Children and Technology Project. Findings indicated race and gender differences in the intensity of IT use; African American males were the least intense users of computers and the Internet, and African American females were the most intense users of the Internet. Males, regardless of race, were the most intense videogame players, and females, regardless of race, were the most intense cell phone users. IT use predicted children's academic performance. Length of time using computers and the Internet was a positive predictor of academic performance, whereas amount of time spent playing videogames was a negative predictor. Implications of the findings for bringing IT to African American males and bringing African American males to IT are discussed.
\end{abstract}

\section{INTRODUCTION}

$\mathbf{T}$ He phrase Digital Divide was coined in the late 20th century to refer to the gap between those who had access to new information technology (IT) and those who did not. ${ }^{1}$ In the United States, the divide was based primarily on income and education, although sociodemographic characteristics, such as race, gender, and age, were also contributors. ${ }^{2}$ Today, digital divide has new meaning. It refers to the gap in the intensity and nature of IT use rather than to the gap in access to it. ${ }^{3,4}$ Our research focused on four questions about the new digital divide among children in the United States: (1) Are there race and gender differences in the intensity of children's IT use, specifically, computer, Internet, videogame playing, and cell phone use? (2) Are there race and gender differences in the nature of children's IT use? (3) Are there parent sociodemographic characteristics that predict the intensity and nature of children's IT use? (4) Is there a relationship between the intensity and nature of children's IT use and their academic performance?

Over a decade of research has documented the existence of a racial digital divide in IT use, particularly in Internet use. ${ }^{4,5}$ Although race differences in Internet access have decreased dramatically, African American adults still use the Internet less intensely than do other racial groups, even when access is not an issue and factors related to Internet use, such as income and education, are controlled. Moreover, the nature of Internet use differs for

\footnotetext{
${ }^{1}$ Department of Psychology; ${ }^{2}$ Department of Education; ${ }^{3}$ Department of American Studies; ${ }^{4}$ Department of Social Work, Michigan State University, East Lansing, Michigan.
} 
African American adults than for other racial groups. Two of the most robust differences are that African Americans are more likely to use the Internet to search for religious/spiritual information and less likely to use it for communication. ${ }^{6}$

In the United States, the gender digital divide in Internet access and intensity of use have all but disappeared. ${ }^{4}$ However, a gender divide in the nature of Internet use persists, at least for adults. Research consistently indicates that adult females are more likely to use the Internet's communication tools, whereas adult males are more likely to use the Internet for information, entertainment, and commerce. $^{8-10}$

Race and gender differences in the intensity and nature of children's Internet use are less well documented than differences for adults. ${ }^{11}$ One might expect fewer differences in the "Net generation," a generation born into an online world, at least in the United States. ${ }^{12}$ Nevertheless, some studies do suggest race and gender differences. ${ }^{11,13,14}$ For example, a study of home Internet use by low-income children found less use by African American than Caucasian American children. ${ }^{15}$ Studies focused on the nature of Internet use consistently find that boys are more likely to play games and girls are more likely to communicate, whether online or using other digital devices. ${ }^{11,16}$

Race and gender differences in the intensity and nature of children's IT use have important implications. Research indicates that media use habits are formed early in life and persist through adulthood. ${ }^{10,17-19}$ Thus, understanding how children use IT is especially important because IT use in childhood foreshadows IT use in adulthood. Other research indicates that the longer an individual has been using IT, particularly the Internet, the more intensely it is used and the more diverse the user's activities become. Moreover, the development of Internet skills, such as navigational skills, is directly related to the amount of time online.

The relationship between children's IT use and their academic performance has been a topic of much discussion but little systematic research. ${ }^{11,15}$ On the one hand, one might expect a positive relationship between the two because the use of technology requires the motivation and skills typically engaged in academic settings. ${ }^{20}$ On the other hand, one might expect a negative relationship to the extent that time using IT, such as the Internet, is time away from more academically focused pursuits, such as reading and writing.

Research relating IT use to academic performance has produced mixed results. ${ }^{11}$ Much of the early research focused on computer use and specific com- puter-based learning applications. A review of this research, which included five meta-analytic reviews, came to the unsatisfying conclusion that the findings were inconclusive. More recent research, focused on Internet use, suggests a positive causal relationship between Internet use and academic performance. ${ }^{15}$ Large-scale national surveys suggest a perceived positive relationship between Internet use and academic performance by students. ${ }^{21}$ For example, in one recent survey, more than $60 \%$ of students age 18 and under said the Internet was "very important" or "extremely important" to doing schoolwork. However, most parents claimed that having the Internet at home had no effect on their children's school grades.

The relationship between videogame playing and academic performance appears to be more unequivocal than the relationship between Internet use and academic performance. Research consistently finds that time spent playing videogames is related to poorer grades in school, as reported by both parents and teachers, and to attention problems in school, as reported by teachers. ${ }^{22}$ However, there is also compelling evidence that playing videogames, online or offline, is causally related to higher visual-spatial skills, ${ }^{23}$ skills viewed by many as fundamental to learning in science, technology, engineering, and mathematics. ${ }^{9}$

The purpose of this research was to examine race and gender differences in children's IT use, defined as computer and Internet use, videogame playing, and cell phone use. Both the intensity and nature of IT use were considered. Parent characteristics such as income, education, and marital status were examined as potential predictors of children's IT use. The relationship between children's IT use and their academic performance was also examined.

\section{METHODS}

\section{Participants and procedures}

Children were recruited from 20 middle schools geographically distributed throughout the southern lower peninsula of Michigan. An additional 100 children were recruited from an afterschool center in Detroit, Michigan. Surveys were distributed by mail to children whose parents agreed to participate in the Children and Technology Project, a 3-year longitudinal study of the impact of technology use on cognitive, social, psychological, and moral development. The project is funded by a grant from the National Science Foundation. All data were collected in late 2005 through early 2006. More infor- 
mation about participants is available on the project Web site (www.msu.edu/user/jackso67/CT/ children/).

\section{Materials}

The Child Survey assessed sociodemographic characteristics and information about school performance in the first section. A section titled Technology Use consisted of questions about the intensity and nature of IT use. More detailed information on the nature of IT use was assessed in the next section by ratings of 38 technology activities. The survey is available from the first author. Parent sociodemographic characteristics were obtained in the Parent Survey completed by the parent/guardian. All measures are described further in the Results section.

\section{RESULTS}

The initial sample consisted of 602 children. Only the 515 children who indicated that they were African American $(n=172)$ or Caucasian American $(n=343)$ were included in the final sample. Mean age was 12.18 years old and not significantly different for the two groups. About half were male (50.3\% and $46.2 \%$ respectively). For $87.8 \%$ of chil- dren, the parent participant in the project was the mother/female guardian.

\section{Intensity of IT use}

Multivariate 2 by 2 (race by gender) analyses of variance (MANOVAs) were performed on the intensity of IT use measures. The main effects of race, $F(6,489)=6.41, p<0.001$, and gender, $F(6,489)=$ $34.35, p<0.001$, were significant, and their interaction approached significance, $F(6,489)=1.98, p<$ 0.07). Means for the analyses are presented in Table 1. Standard deviations for these and all other measures are available from the first author. F-ratios for significant univariate effects ranged from 3.82 to 165.14, $d f_{\text {error }}=446$.

Caucasian American children had been using computers longer than had African American children; males had been using computers longer than had females. However, a race by gender interaction on this measure indicated that both effects were attributable to African American males having used computers for less time than any other group. Similarly, African American males used both computers and the Internet less often than did any other groups. In contrast, African American females led the way in intensity of Internet use, using the Internet more often than did any other group.

Table 1. Means for the Race by Gender Analyses of the Intensity of IT Use

\begin{tabular}{llcr}
\hline & & AfAm & $\begin{array}{c}\text { CaAm } \\
\mathrm{n}=343\end{array}$ \\
\hline How long have you been using a computer? & Males & $4.69(1.29)$ & $5.21(1.13)$ \\
& Females & $5.17(1.08)$ & $5.29(0.91)$ \\
How often do you use a computer? & Males & $4.06(1.52)$ & $4.57(1.31)$ \\
& Females & $4.31(1.47)$ & $4.27(1.21)$ \\
How long have you been using the Internet? & Males & $4.18(1.43)$ & $4.54(1.33)$ \\
& Females & $4.86(1.28)$ & $4.66(1.20)$ \\
How often do you use the Internet? & Males & $3.72(1.60)$ & $3.98(1.43)$ \\
How often do you play videogames? & Females & $4.36(1.43)$ & $3.98(1.34)$ \\
& Males & $4.82(1.58)$ & $4.85(1.42)$ \\
How often do you use a cell phone? & Females & $3.05(1.45)$ & $2.98(1.55)$ \\
& Males & $2.82(1.97)$ & $2.48(1.65)$ \\
& Females & $4.07(2.12)$ & $2.91(1.75)$ \\
\hline
\end{tabular}

AfAm, African American; CaAm, Caucasian American.

Numbers in parentheses are standard deviations.

Scales were as follows:

Length of use: 1 = I never use; 2 = less than 1 year; 3 = about 1 year; $4=1-2$ years; $5=2-5$ years; $6=$ more than 5 years.

Frequency of use: 1 = I don't use; 2 = about once a month; $3=$ a few times a month; $4=$ a few times a week; 5 = everyday for less than 1 hour; 6 = everyday for $1-3$ hours; 7 = everyday for more than 3 hours. 
A main effect of gender on videogame playing indicated that males played videogames more than did females. No other effects were significant. In contrast, all three effects were significant for the measure of cell phone use. Females used cell phones more than did males, and African American children used them more than did Caucasian American children. However, African American females used them most, and Caucasian American males used them least. There was no difference in cell phone use between African American males and Caucasian American females.

\section{Nature of IT use}

Two by two (race by gender) MANOVAs were performed on the 38 items assessing the nature of IT use. The main effects of race, $F(38,413)=5.11$, $p<0.001$, and gender, $F(38,413)=2.99, p<0.001$, were significant, as was their interaction, $F(38$, $413)=2.07, p<0.001$. Means and standard deviations for univariate analyses are available from the first author. Only those effects significant at $p<0.01$ are discussed $\left(6.28<F<49.51, d f_{\text {error }}=446\right)$.

Main effects of race unqualified by a race by gender interaction indicated that African American children were more likely than Caucasian American children to use the Internet to search for information about religious/spiritual information and jobs. All other race effects were qualified by the race by gender interaction. African American females were most likely and African American males least likely to surf the Web, buy something online, search the Internet for something needed for a school report, search the Internet for information about a hobby or interest, and use a search engine.

Gender effects unqualified by the race by gender interaction indicated that females were more likely than males to instant message with friends, create documents for school, save images/graphics, take a survey online, take a test online, read mailing list messages, and use e-mail.

Other race by gender interactions indicated that African Americans, but especially African American females, were more likely than Caucasian Americans to text message using a cell phone. African American females were most likely and Caucasian American females were least likely to download music files. African American females were most likely compared to all other groups to search for information about depression, mood, and mental illness; to search for news and current events; and to exchange photos. African American females were most likely and Caucasian American males least likely to search for information about health, diet, and fitness.

\section{Parent characteristics, IT use, and academic performance}

The first question addressed by regression analyses was whether parent sociodemographic characteristics, namely income, education, marital status (married living with spouse versus other), and employment status (employed full time versus other), predicted children's IT use. Four measures of IT use served as criteria in separate regression analyses: length of IT use ( 2 items, $\alpha=0.80$ ); frequency of IT use ( 2 items, $\alpha=0.83$ ); frequency of videogame playing; frequency of cell phone use. Two measures of academic performance served as criterion: usual grades in school $(1=$ mostly A's, $5=$ mostly failing grades); overall GPA.

Parent income and education each made a unique contribution to predicting how long children had been using IT $\left(F(4,483)=10.97, p<0.001, \beta_{\text {income }}=\right.$ $0.18, \beta_{\text {education }}=0.14, p s<0.01$; adjusted $R^{2}=0.08$ ), but marital and employment status did not. Children whose parents had more education and income had been using IT longer. Parent education marginally predicted how frequently children used IT $\left(F(4,482)=3.34, p<0.01, \beta_{\text {education }}=0.09, p<\right.$ 0.06 , adjusted $R^{2}=0.01$ ). Children whose parents had more education used computers and the Internet more often.

Parent marital status was the only predictor of videogame playing $\left(F(4,482)=2.31, p<0.05, \beta_{\text {mar- }}\right.$ ital $=-0.13, p<0.01)$. Children whose parents were married and living together spent less time playing videogames than did children whose parents were some other marital status (e.g., single). Cell phone use $(F(4,484)=1.95, p<0.1)$ was predicted by parent employment status $\left(\beta_{\text {employment }}=-0.11, p<\right.$ 0.05). Children whose parents were employed full time used cell phones more frequently than did those whose parents were some other employment status.

Regression analyses to predict academic performance from IT use resulted in significant effects for both grades in school $(F(4,449)=10.73, p<0.001$, adjusted $\left.R^{2}=0.07\right)$ and GPA $(\mathrm{F}(4,326)=10.72, p<$ 0.001 , adjusted $R^{2}=0.11$ ). Children who had been using IT longer had higher grades in school $(\beta=$ $0.27)$ and higher GPAs $(\beta=-0.23)$ than did children whose IT use was more recent. These effects cannot be attributed to age. Indeed, there was a negative relationship between age and academic performance. 
Children who played videogames more had lower grades in school $(\beta=0.16)$ and lower GPAs $(\beta=-0.20)$ than those who spent less time playing videogames. Cell phone use did not predict academic performance.

\section{DISCUSSION}

Findings addressing our four research questions indicate that (1) there are race and gender differences in the intensity of children's IT use; (2) there are race and gender differences in the nature of children's IT use; (3) parent sociodemographic characteristics predict the intensity and nature of IT use; (4) intensity and nature of IT use predict academic performance.

With respect to the intensity of IT use, African American males were the least intense users of computers and the Internet, whereas African American females were the most intense users of the Internet. Males, regardless of race, were the most intense videogame players. Females, particularly African American females, were the most intense users of cell phones, and Caucasian American males were the least intense cell phone users.

With respect to the nature of IT use, race and gender effects were frequently qualified by their interaction, which rather consistently indicated that African American females use the Internet more intensely and in more diverse ways than does any other group, whereas African American males use it less intensely and in fewer ways than does any other group. Indeed, the only effect of race unqualified by its interaction with gender indicated that African Americans were more likely to search for religious/spiritual information and information about jobs than were Caucasian Americans, consistent with research on the Internet behavior of adults. ${ }^{7}$

Also consistent with previous research, females were more likely than males to use technology to connect with others. ${ }^{4,8,11}$ Females, regardless of race, instant messaged with friends and used email more than did males. Females were also more likely than males to use the Internet for academic purposes.

Other race by gender interactions support the view that African American females have embraced IT. They led all other groups in text messaging using a cell phone, downloading music files, and searching the Internet for a variety of information, including information about physical and mental health and well-being.
Children's IT use predicted their academic performance. Children who had been using IT longer had higher grades in school than those who were more recent users, an effect that cannot be attributed to age. Children who played videogames more often had lower grades in school than those who spent less time playing videogames. Of course, the correlational nature of our research precludes conclusions about cause and effect. However, taken together with previous research demonstrating a causal relationship between frequency of Internet use and favorable academic outcomes in a comparable sample of low-income youth, ${ }^{15}$ our findings encourage efforts to establish not only causality but also what it is about Internet use that contributes to children's academic performance.

Overall, our findings suggest a new digital divide based on the interaction of race and gender. African American females have embraced IT, often surpassing in use the presumed technophile, the Caucasian American male, especially in use of the Internet. However, African American males lag behind other groups in their IT use, with one notable exception: videogame playing. African American males played videogames as much as did Caucasian American males and more than did females, regardless of race. Unfortunately, videogame playing is the only IT use linked in this and previous research to poorer academic performance. ${ }^{22}$ Moreover, playing violent videogames has consistently been linked to aggressive behavior. ${ }^{24}$

Our findings suggest that educational and community interventions should focus on two related objectives: bringing IT to African American males and bringing African American males to IT. One way to achieve both objectives is to introduce IT, particularly computers and the Internet, early in the lives of young African American males. Parents, educators, and the community should play a role in making IT available and encouraging its use. A second way to achieve these objectives is to capitalize on African American males' existing interest in videogame playing, turning this interest from a potential liability to a potential asset with respect to academic performance. Researchers and technologists have recently intensified efforts to make videogames more efficacious tools for learning, as evidenced by a recent issue of the Communications of the ACM devoted entirely to this topic. ${ }^{25}$ Greater understanding of the user side in this development, particularly the young African American males user, holds promise for changing a negative relationship between videogame playing and academic performance into a positive one. 


\section{ACKNOWLEDGMENTS}

This research was supported by a grant from the National Science Foundation (HSD\#0527064). Details about the Children and Technology can be found at www.msu.edu/user/jackso67/CT/children/index.htm.

\section{REFERENCES}

1. Norris P. (2001) Digital divide: civic engagement, information poverty, and the Internet worldwide. New York: Cambridge University Press.

2. Pew Internet and American Life Project. (2002) The digital disconnect: the widening gap between Internet-savvy students and their schools. www.pewinternet.org/pdfs/PIP_Schools_Internet_Report.pdf (accessed May 27, 2008).

3. van Dijk J. (2005) The deepening divide: inequality in the information society. Thousand Oaks, CA: Sage.

4. Pew Internet and American Life Project. (2006) Internet usage trends: through the demographic lens. www.pewinternet.org/ppt/Fox_FTC_Nov_6_\%2020 06.pdf (accessed May 27, 2008).

5. Hoffman D, Novak T, Schlosser A. (2001) The evolution of the digital divide: examining the relationship of race to Internet access and usage over time. In Compaine $\mathrm{B}$, ed. The digital divide. Cambridge, MA: MIT Press, pp. 36-59.

6. Jackson LA, Ervin KS, Gardner PD, et al. The racial digital divide: motivational, affective, and cognitive correlates of Internet use. Journal of Applied Social Psychology 2001; 31:2019-46.

7. Pew Internet and American Life Project. (2000) African-Americans and the Internet. www.pewinternet.org/pdfs/PIP_African_Americans_Report.pdf (accessed May 27, 2008).

8. Jackson LA, Ervin KS, Gardner PD, et al. Gender and the Internet: women communicating and men searching. Sex Roles 2001; 44:363-80.

9. Subrahmanyam K, Greenfield P, Kraut R, et al. (2001) The impact of computer use on children's and adolescents' development. Applied Developmental Psychology 2001; 22:7-30.

10. Valkenburg M, Soeters P. Adolescents' exposure to sexually explicit material on the Internet. Communication Research 2006; 33:178-204.

11. Jackson LA. (2008) Adolescents and the Internet. In Romer D, Jamieson P, eds. The changing portrayal of American youth in popular media. Annenberg Public Policy Center at the University of Pennsylvania. New York: Oxford University Press, pp. 377-410.
12. Tapscott D. (1998) Growing up digital: the rise of the Net generation. New York: McGraw-Hill.

13. Internet Statistics Information System. (2007) Internet usage statistics. http://isis.nida.or.kr/index_unssl. jsp (accessed April 2006).

14. Wasserman IM, Richmond-Abbott M. Gender and the Internet: causes of variation in access, level, and scope of use. Social Science 2005; 86:252-70.

15. Jackson LA, von Eye A, Biocca FA, et al. (2006) Children's home Internet use: predictors and psychological, social and academic consequences. In Kraut R, Brynin M, Kiesler S, eds. Computers, phones and the Internet: domesticating information technology. New York: Oxford University Press, pp.145-67.

16. Wartella E, Caplovitz AG, Lee P. Internet use and well-being in adolescence. Journal of Social Issues 2004; 58: 75-90.

17. Howard P, Raine L, Jones S. Days and nights on the Internet: the impact of a diffusing technology. American Behavioral Scientist 2001; 45:383-404.

18. Pruijt H. Social capital and the equalizing potential of the Internet. Social Science Computer Review 2002; 20:109-15.

19. Roberts DF, Foehr U, Rideout V. (2004) Kids and media in America. New York: Cambridge University Press.

20. Bonfadelli H. The Internet and knowledge gap: a theoretical and empirical investigation. European Journal of Communication 2002; 17:65-84.

21. Annenberg Digital Future Project. (2004) Surveying the digital future-year 4: ten years, ten trends. www.digitalcenter.org/downloads/DigitalFutureReport-Year4-2004.pdf (accessed May 27, 2008).

22. Walsh D, Gentile DA, Walsh E, et al. (2006) National Institute on Media and the Family. 11th Annual Video Game Report Card, MediaWise®. www.mediawise.org.

23. Green CS, Bavelier D. Action video experience alters the spatial resolution of vision. Psychological Science 2007; 18:88-94.

24. Anderson CA, Gentile DA, Buckley KE. (2007) Violent video game effects on children and adolescents: theory, research and public policy. New York: Oxford University

25. Zyda M. Creating a science of games. Communications of the Association for Computing Machinery 2007; 50: whole issue.

Address reprint requests to: Dr. Linda A. Jackson Department of Psychology Michigan State University East Lansing, MI 48824

E-mail: jackso67@msu.edu 
Copyright of CyberPsychology \& Behavior is the property of Mary Ann Liebert. Inc. and its content may not be copied or emailed to multiple sites or posted to a listserv without the copyright holder's express written permission. However, users may print, download, or email articles for individual use. 